\title{
CONCEPTUAL FRAMEWORK OF CULTURAL BACKGROUND IN THE LIT ENVIRONMENT
}

\author{
Izmir Tunahan G. ${ }^{1}$, Altamirano H. ${ }^{1}$ and Unwin Teji J. ${ }^{1}$ \\ ${ }^{1}$ Institute for Environmental Design and Engineering, University College London, \\ London, United Kingdom
}

gizem.izmir.tunahan.17@ucl.ac.uk

\begin{abstract}
In environmental terms, culture represents the climatic and indoor conditions people have experienced during a significant part of their life. Consequently, people exposed to different cultures might have different expectations of the lighting environment. Knowing the lighting expectations due to cultural experiences have numerous advantages; it could help meet the occupants' needs and preferences and provide occupant satisfaction, reducing unnecessary energy consumption in the built environment. This paper aims to summarise a systematic review to create a conceptual framework of cultural background in the lit environment, which could help understand the impact of cultural background on daylight perception and expectation. This review highlighted that cultural background in lighting environment should be evaluated considering (1) the ethnicity and/or physiological characteristics of the individual eyes, (2) the area (luminance environment) where people used to live (3) the luminance environment they were recently exposed to and (4) the socio-cultural background of individuals. Future research should further test these components together and separately to investigate which component or combination is more influential on daylight perception.
\end{abstract}

Keywords: Daylight, Cultural background, Daylight perception, Residential area.

\section{Introduction}

'Culture' is a broad subject, and generally accepted use of culture refers to people's general customs and beliefs. However, Pierson, Wienold and Bodart (2018) have put forward a new definition of culture as "the climatic and indoor conditions which people experienced during their major part of life." As a result of the cultural experiences, human behaviours toward the environment and its expectations are shaped. Consequently, people exposed to different cultures might have different expectations of the lighting environment. Lighting research to date has focused on the impact of cultural background on glare discomfort perception rather than daylight perception and satisfaction (Pierson, Wienold and Bodart, 2018). Also, researchers' approaches to the cultural background concept vary. The cultural components are defined differently because the cultural background concept in the lighting environment has not been comprehensively described yet. Knowing people's lighting expectations due to cultural experiences have numerous advantages; it could help meet the occupants' needs and preferences and provide occupant satisfaction, which in turn help reduce unnecessary energy consumption in the built environment.

This paper discusses the association between cultural background and daylight perception, expectation, and satisfaction. The paper presents and discusses a systematic review to create a conceptual framework of cultural background in the lit environment, which could help understand the impact of cultural background on daylight perception and expectation. 


\section{Methodology}

\subsection{Framing questions for a review}

The systematic review is reported following the PRISMA (Preferred Reporting Items for Systematic Review and Meta-Analysis) Checklist (Moher et al., 2010). Published studies in this field consist of various quantitative and qualitative studies, designed as correlational, cross-sectional, longitudinal, or retrospective, often with specific contexts and small sample sizes. Thus, the range of the reviewed study methodologies includes environments that are analogous in some ways to the situations that people will encounter.

\section{Inclusion and exclusion criteria}

The inclusion criteria were: (a) including at least one aspect of (day)lighting perception, (b) published in English, peer-reviewed journals excluding conference proceedings and books, and (c) published during any year from 1990 to November 2019. Scopus, Web of Science, and LEUKOS were searched for electronic records using the following keywords and Boolean search terms. Boolean operators are utilised by defining the main research question's keywords and their synonyms. They make the search more accessible by using AND to combine the keywords, OR to broaden and NOT to eliminate. The Boolean search was done in this way: The keywords in Group 1 (Culture* OR "Prior light history" OR "Previous light history" ..) AND the keywords in Group 2 ("Daylight perception" OR "Light perception" OR "Daylight expectation"...)

The potentially relevant articles and papers were identified by defining keywords (Table 1) which were searched within each database using the combination of the keywords from Group 1 and Group 2 (Boolean search terms). The search was done in either title, abstract, or keywords of the papers in the Scopus and Web of Science databases. Keywords were searched anywhere in the high-quality Light and Lighting database (LEUKOS) because the database did not allow to search in abstract or title. After downloading the papers from LEUKOS, they were eliminated manually so that they met the identified criteria.

Table 1 - Used keywords in the systematic review

\begin{tabular}{|c|c|c|}
\hline Databases & Group 1: Intervention & Group 2: Outcome \\
\hline $\begin{array}{c}\text { Scopus } \\
\text { In Article title, Abstract } \\
\text { or Keyword } \\
\text { Web of Science } \\
\text { In Article title, Abstract } \\
\text { or Keyword } \\
\text { LEUKos } \\
\text { In anywhere, } \\
\text { then manually checked } \\
\text { if it applies to criteria }\end{array}$ & $\begin{array}{c}\text { Culture } \\
\text { Prior/Previous light history } \\
\text { Prior/ Previous } \\
\text { Iuminous environment } \\
\text { Previous climatic conditions } \\
\text { Daylight experience } \\
\text { Luminance history } \\
\text { Long term light experience } \\
\text { Past daylight experience } \\
\text { Local illuminance } \\
\text { Country of origin } \\
\text { Latitude } \\
\text { Immigrant } \\
\text { Sociocultural } \\
\text { Vitamin D }\end{array}$ & $\begin{array}{l}\text { (Day)light perception } \\
\text { (Day)light expectation } \\
\text { (Day)light satisfaction } \\
\text { User expectations } \\
\text { (Day)lighting sensitivity } \\
\text { (Day)lighting tolerance } \\
\text { (Day)light adaptation } \\
\text { Visual comfort } \\
\text { Discomfort glare }\end{array}$ \\
\hline
\end{tabular}




\subsection{Identifying relevant work}

In the first stage of the screening phase, the titles and abstracts of the journal articles were reviewed and manually excluded if they did not meet the criteria mentioned above. The second stage was the assessment of the full-text articles for eligibility based on the method outlined in PRISMA. The results of the eligible studies were exported to Mendeley, which identified 1189 published research articles. Then the duplicates were removed $(n=28)$. Next, if the title or abstract did not provide appropriate information or meet the selection criteria, they were removed $(n=1126)$. These papers mostly involved Biology and Photobiology studies on animals, especially rats and some phytoplankton cells. The considered only included those where the association between cultural background and daylight perception (insufficiency (quantity) and inefficiency (quality)), including daylight adequacy and discomfort glare, were assessed.

Then the remaining full-text articles $(n=35)$ were assessed for eligibility, of which 27 papers were excluded from further inclusion as they were deemed irrelevant (e.g., circadian rhythm studies). Finally, the exclusion resulted in eight relevant journal papers that were analysed further for method and content (Appendix 1). Figure 1 shows the process of inclusion of reviewed papers. In addition to the database search, a manual search of all references cited was conducted in relevant articles. This process led to the identification of 39 published articles of potential relevance. These articles were then considered for inclusion in the systematic review according to the inclusion and exclusion criteria described below.

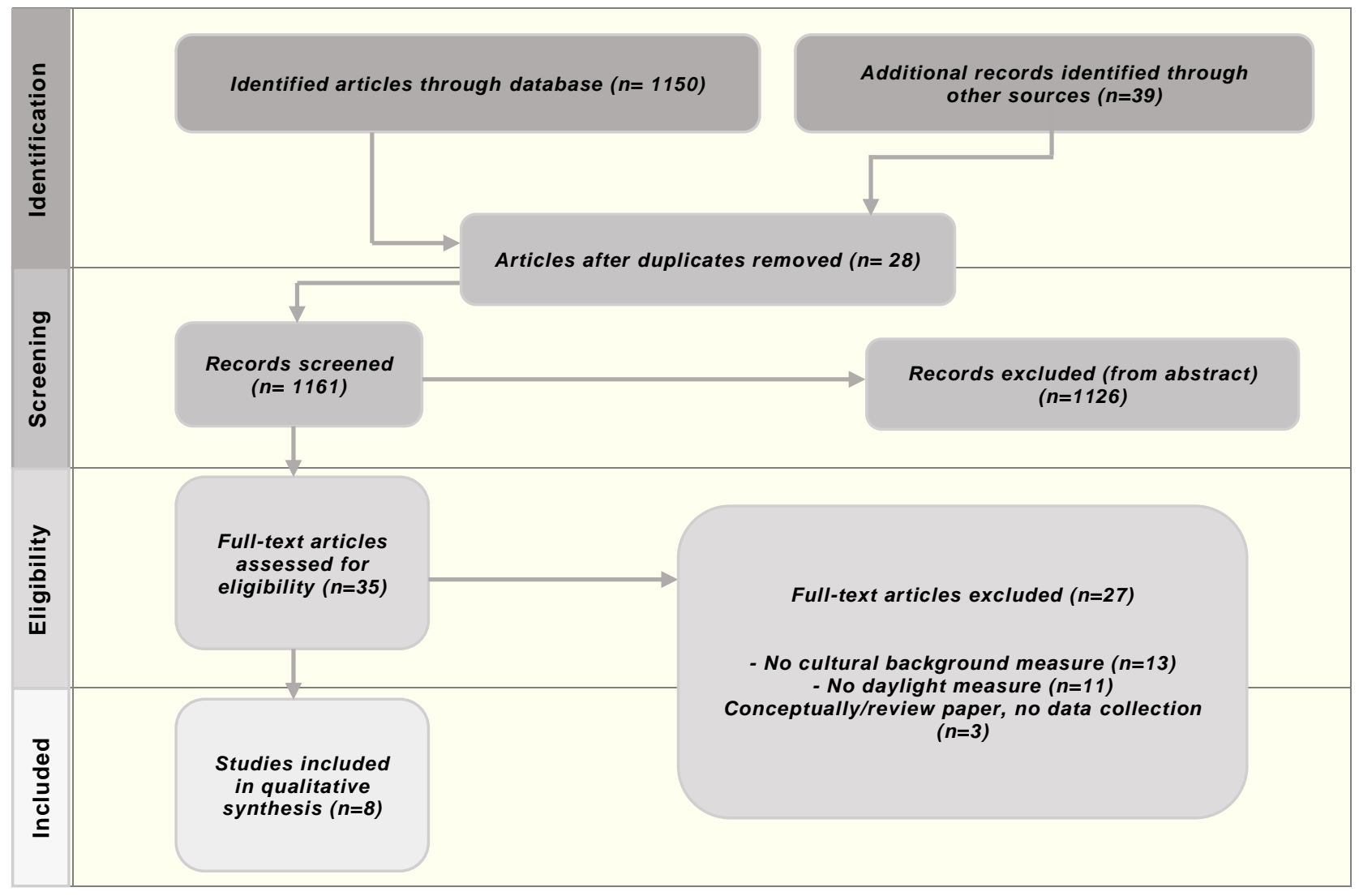

Figure 1 - Flow of information through the different phases of the systematic review The number of studies included in the qualitative synthesis $(N=8)$ 


\section{Results and discussion}

The selected published articles (Appendix 1) were analysed according to their approach to cultural background. Even though all studies focused on the association between cultural background and daylight perception, they all understand and define "culture" differently. The definitions given to cultural background refer to ethnicity and genetic origin, geographic location of residence, previous luminous environment, and sociocultural context.

\subsection{Ethnicity and genetic origin approach}

Up to now, various criteria have been used to assess ethnicity (e.g., country of birth, nationality, skin colour, national/geographical origin, and religion and language spoken at home (Office for National Statistics, 2018). However, it has not been described using only one criterion, but a combination of them. In the lighting environment, the ethnic background has been found to affect light perception, specifically discomfort glare perception, assessed through discomfort glare indices. These indices were developed to compare subjects from different studies and to account for differences in the visual properties of particular groups. Indices such as the DGI for British subjects (Hopkinson, 1971), PGSV for Japanese subjects (Tokura, Iwata and Shukuya, 1996), and DGP for German and Danish subjects (Wienold and Christoffersen, 2006) were designed for specific groups and, therefore, their thresholds and the interpretation of findings differ from each other.

Several researchers have assessed subjects from different locations and their discomfort glare perception. For instance, Subova et al. (1991) highlighted the difference in the subjective responses to discomfort glare between subjects in Slovakia and subjects from a similar study conducted in the USA by MacGowan et al. (1988). Furthermore, IWATA et al. (1992) studied the difference in discomfort glare sensitivity between Japanese and British subjects. They found that Japanese subjects were less sensitive to higher levels of discomfort glare than British subjects; although, the compared study procedures were not completely the same. In contrast, Pulpitlova and Detkova (1993) found similar discomfort glare level evaluations from Slovakian subjects compared to American subjects (MacGowan and Emery 1986) by using Hopkinson's discomfort glare scale. Thus, some researchers found either similarities or differences between discomfort glare perception of people from different ethnicities. It may be the result of the application of different indices and study designs.

Lee and Kim (2007) found that Caucasians felt more discomfort glare at high luminance $(15,000$ lux $)$ than Asians. However, they ignored participants' area of residence and prior light history and assumed that participants living in the same locations have the same ethnic background. A glare perception study done by Kent et al. (2016) could not find any correlation between ethnicity and subjects' glare assessments. However, they found a significant difference in discomfort glare perception of people from different ethnicities in their further studies.

These studies show that ethnicity may be a critical factor leading to how lighting conditions are perceived. Nevertheless, subjects with different ethnic backgrounds may have similar discomfort glare perceptions as long as they lived in the same province and got used to living under those conditions. Therefore, which location participants were selected from, in other words, study design has great importance in interpreting the findings. All of this shows that ethnicity alone cannot be used to predict discomfort glare perception of subjects. For this reason, researchers began to study the properties and visual characteristics of subjects' eyes.

Van den Berg et al. (1991) investigated the optical characteristics and iris colour of Caucasians and Asians and found a variation in light acceptance, resulting in different pigmentation densities between subjects' eyes. Also, Lee and Kim (2007) supported the previous study by showing that Caucasians have less tolerance to high glare levels than Asians due to the physiological properties of the eyes. A remarkable difference was also found between suppressing the production of the hormone melatonin in light-eyed Caucasians and that in dark-eyed Asians (Higuchi et al., 2007). This study demonstrated that the difference in light-based melatonin suppression is associated with eye pigmentation and/or 
ethnicity.

Many studies have demonstrated differences in daylight perception and preferences resulting from ethnicity and/or individual eyes' physiological properties. However, most crosscultural lighting studies examined discomfort glare perception and colour temperature preference, but they did not sufficiently focus on the adequacy of illuminance levels. Nonetheless, Belcher (1985) argued that understanding cross-cultural illumination preferences are critical since it can affect feelings of well-being and worker productivity.

\subsection{The geographic location of residence}

Many researchers have shown that subjective lighting assessments of the same environment are not often consistent. This might result from the acclimatisation of individuals to specific outdoor daylight conditions. For instance, residents in Tel Aviv, where illuminance levels are above 75,000 -lux for around $66 \%$ of the time, may not have the same daylight expectation as people living in Berlin, where similar levels of illuminance barely occur. Hence, external illuminance conditions might have significant effect on daylight perception, preference, and expectation. However, the amount of exposed daylight also matters in addition to outdoor illuminance levels. Hence, the development of a universal index is difficult due to the distinct cultural differences in illuminance preferences (Belcher, 1985).

Pierson, Wienold and Bodart (2018) proposed that even if the subjects had different ethnical backgrounds, their lighting perceptions were similar because they had been accustomed to the same climatic and environmental conditions resulting from living in the same place. Kim and Mansfield (2016) noticed a cultural difference in the appraisal path between people living in the UK and South Korea. Similarly, Saraiva et al. (2018) found several similarities in climate conditions between students from two different cities in Portugal and Brazil. $80 \%$ of the students in Brazil and $78 \%$ in Portugal stated that they were satisfied with the indoor lighting environment in their classroom. Despite these two cities' cultural diversity and location, the students' comfort levels seemed comparable, probably due to similar climate conditions they were accustomed to.

Another comparative study between Korean and American subjects showed that Korean immigrants into the US expressed their discomfort with local conditions and how challenging it was to accustom to such different lighting conditions (Lee, 2007). Likewise, some researchers found a noticeable difference in the lighting perception of people living at different latitudes or altitudes. A comprehensive study conducted by Subova et al. (1991) found that subjects in Middle Europe, living around 30 degrees, might have higher sensitivity because of their adaptability to lower luminance conditions. Brandl and Lachenmayr (1994) also showed that altitude change causes some physiological alteration in the human body, and the participants in their experiment indicated different light sensitivity at different altitudes.

Acclimatisation to outdoor daylight levels might affect subjective evaluations of artificial light as well as daylight. A cross-cultural study was conducted by Bodrogi et al. (2017) about the preference for perceived illumination chromaticity among Chinese and European observers. In the study, participants were divided into Chinese and European origin, living in Germany and China. Interestingly, they found similarities in participants' lighting preferences varied depending on where they live instead of their ethnic backgrounds. Another comprehensive field study was conducted to better understand the customers' lighting satisfaction in eight shopping malls across China at four locations (Shanghai, Nanjing, Langfang, and Harbin) with various climatic, economic, and cultural characteristics (Jin et al., 2017). This study found a strong association between the presence of daylight and occupant satisfaction $(p<0.05)$. It shows that people tend to be more satisfied with the conditions they are accustomed to.

Taken together, all these studies demonstrate that people living in the same place and getting used to experiencing under those conditions tend to have similar lighting preferences. However, these studies only considered the lighting conditions that the participants were 
exposed to and did not involve individual differences resulting from the climatic and cultural diversity of the locations such as ethnic background, lifestyle (how much daylight the individual exposed in a typical day), and sociocultural norms.

\subsection{Previous luminous environment}

The term "Zeitgeber" is used as a time giver or synchroniser in the field of chronobiology. It is considered as an external cue that synchronises an organism's biological rhythms to the Earth's 24-hour light and dark cycle. The circadian clock features prominently in coordinating biochemical, physiological, and behavioural processes; thus, zeitgebers are vital in human biological rhythms. There are two types of zeitgebers: photic and non-photic, and these components are light, atmospheric conditions, medication, temperature, social interactions, exercise, and eating/drinking patterns. Even though each of these components is linked to each other, lighting takes the lead as the most potent cue to synchronise the circadian clock (Chellappa et al., 2014).

Lighting is perceived only from the retina with the aid of different types of photoreceptors: rods, cones, and recently discovered ipRGCs. Several pieces of research showed that rods and cones play a crucial role in the image-forming vision, whereas the ipRGCs are responsible for the non-image-forming vision. This non-image forming photoreceptive system takes part in the regulation of several functions. However, the impact of lighting depends on the intensity, duration, wavelength, and timing of light exposure (Chellappa, Gordijn and Cajochen, 2011). Nevertheless, there has been very little research directly investigating the effect of the previous luminous environment and its consequent outcomes (Smith, Schoen and Czeisler, 2004).

The previous luminous environment represents the lighting conditions a subject experienced in a specific period. This period may vary from hours and days to weeks and years. Previous studies primarily defined prior photic history as the intensity and duration of prior light exposure. They also demonstrated that the amount of exposed daylight while spending time outside or sitting indoors by a window is significant because prior lighting conditions determine how much melatonin suppressing response to daylight and, ultimately, how we perceive and evaluate lighting conditions. For instance, an individual who spends time outside most of the day may not evaluate daylight conditions as the same as another person who generally spends time indoors even if they live in the same place under the same outdoor illuminance conditions.

Few studies have shown that long-term exposure to low light levels might cause higher sensitivity in the rods and may increase the time of light adaptation (Spitschan, 2019). Besides, a study conducted by Chang, Scheer and Czeisler (2011) indicated that exposure to a very dim light level caused significantly more phase shifting response (60-70\%) rather than a typical room light level exposure. Also, long term daylight deprivation has a remarkable impact on participants' sleep-wake patterns and retinal sensitivity after seven months without sunlight $(p<0.05)$ (Kawasaki et al., 2018). This view was supported by Martin et al. (2002), who showed that subjects would become less sensitive to light after a week of increased daytime bright-light exposure and that if they are restricted to the dimmer light, they would become more sensitive. The researchers proved significantly more melatonin suppression after a week of exposure to relatively dim light compared with after a week of exposure to long durations (about $4 \mathrm{hr}$ per day) of brighter light. In addition to this, they found higher light sensitivity after the dim week when compared with the bright week. Likewise, in Kawasaki et al. (2018), the exposure time period was extended to seven months to test whether retinal sensitivity, sleep, and circadian rest-activity cycle change during long-term daylight deprivation. They evaluated participants' retinal sensitivity changes towards different lighting stimuli and measured the rest-activity cycle using activity watches. They found an increase in retinal sensitivity to blue light, whereas a decrease in circadian rhythm stability and delay of sleep-wake timing during long-term daylight deprivation. 
These studies have shown that the issue of prior light history needs considerable attention as much as other approaches, and prior light history arising from the previous luminous environment has an essential impact on light perception as well as sleep-wake patterns, mood, and cognition.

The study design also matters in the interpretation of the findings because most studies in the literature have limited observation time (mostly a week). However, the amount of daylight exposed for a short period of time may not change the participants' lighting evaluations. For instance, if an individual generally spending time indoors is exposed to high daylight conditions for a week, his internal clock may not be affected (it takes some time to adjust), and his lighting perception may be the same as previous regardless of the exposure time and the outdoor illuminance conditions in the last week. Therefore, prior light history should be considered under (1) the combination of outdoor daylight availability and (2) the subject's lifestyle and preferences for (3) a sufficient time.

\subsection{Sociocultural context}

As mentioned earlier, the subjective assessment of the same lighting conditions differs from person to person. This variation might be based on socio-cultural context, and ultimately values, customs, and traditions rather than acclimatisation to some kinds of lighting conditions. Individuals who share the same socio-cultural background might judge the conditions similarly or have identical behaviour patterns. Hence, they may have common attitudes and perceptions towards daylight conditions.

Siu-Yu Lau, Gou and Li (2010) tested whether daylight helps to increase the satisfaction of residential buildings in Hong Kong. In contrast to other researchers, they assessed humanwindow interaction in terms of cultural norms. The study results showed that daylighting was not a dominant factor for residents in domestic window design in Hong Kong, but other factors such as dining habits, views from the living room, and privacy for the bedroom were proved to be more important in the users' perception because of socio-cultural context. Therefore, in some cultures, lighting conditions may not be a primary factor because of the socio-cultural context and lifestyle, so their perception and expectations vary from people living in another cultural background.

Lee (2007) confirmed that Korean temporary residents in the United States found it difficult to accustom to interior lighting conditions. This could be linked to their socio-cultural background and traditions because Koreans value a south-facing house with high daylight illumination levels (Hong, 1975). Similarly, Park, Pae and Meneely (2010) found that Koreans preferred high-intensity light differently from Americans. Koreans also stated that bright lighting arouses them than dim lighting in contrast to Americans. Furthermore, Quellman and Boyce (2002) studied light source colour preferences of European, Asian, Indian, African, and North American people, classifying them depending on skin tones. Their results showed a noticeable between cultural backgrounds. Europeans with the lightest skin type preferred warm light sources, and Asians generally chose light sources with a white colour temperature because whiteness symbolises health in their culture. These studies showed that Korean people specifically value high-intensity lighting, brightness, and white colour temperature. Besides, even though these studies were conducted in various locations, Korean people's judgements were similar regardless of their geographic location of residence and previous light history.

From another point of view, individual lifestyle and daily routines may be related to sociocultural background and behavioural factors that are not mostly accounted for in many studies, which may affect the perception of lighting quality. For instance, some individuals tend to spend more time outdoors culturally, and their lighting evaluation could vary from those spending mostly indoor due to high levels of light exposure. 
Taken together, all these studies indicate that there is an impact of socio-cultural background and possibly related perceptional and behaviour patterns on daylight perception within the individual and contextual variability. For this reason, further research should be undertaken, and both socio-cultural and individual variations should be considered together.

\section{Conclusion}

This review aimed to create a conceptual framework of cultural background in lit environments to investigate an association between cultural background and daylight perception, expectation, and satisfaction. The review showed that factors thought to be influencing daylight perception in the cultural context have been explored in several ways. It firstly demonstrated that ethnicity and/or physiological properties of individual eyes affect daylight perception and preferences. Secondly, it provided evidence for the importance of the residential area's impact on the daylight perception of the people living in the same location and getting used to experiencing those conditions. Thirdly, it remarked the importance of the previous luminance environment and suggested that the prior light history should be considered under the combination of outdoor daylight availability and the subject's lifestyle and preferences for a sufficient time. Lastly, it stated that socio-cultural background and possibly related behaviour patterns impact daylight perception within the individual and contextual variability. Together these results provide valuable insights into daylight perception in the cultural context.

This review has confirmed the assumption that there are differences in how people perceive and feel about different lighting conditions due to their cultural background with various approaches. It also has remarked the lack of comprehensive knowledge of this issue regarding the perceived adequacy of illumination for people from different cultural backgrounds. A further study with more focus on daylight perception with the combination of the four cultural background approaches explained previously is therefore recommended. Also, more research on which approach is more influential on daylight perception needs to be undertaken before the association between cultural context and daylight perception is more clearly understood.

\section{Funding}

This document has been produced with the financial assistance of the Ministry of National Education of Turkey. The funder had no role in the design of the study; in the collection, analyses, or interpretation of the data.

\section{References}

van den Berg, T. J. T. P., ljspeert, J. K. and de Waard, P. W. T. (1991) 'Dependence of intraocular straylight on pigmentation and light transmission through the ocular wall', Vision Research, 31(7-8), pp. 1361-1367. doi: 10.1016/0042-6989(91)90057-C.

Bodrogi, P. et al. (2017) 'Intercultural observer preference for perceived illumination chromaticity for different coloured object scenes', Lighting Research and Technology. doi: $10.1177 / 1477153515616435$.

Brandl, H. and Lachenmayr, B. (1994) 'Sensitivity of the central visual field dependent on hemoglobin-oxygen saturation', Ophthalmologe, 91(2), pp. 151-155.

Chang, A. M., Scheer, F. A. J. L. and Czeisler, C. A. (2011) 'The human circadian system adapts to prior photic history', Journal of Physiology, 589(5), pp. 1095-1102. doi: 10.1113/jphysiol.2010.201194.

Chellappa et al (2014) ‘How light affects our brain's performance: Photic memory for executive 
brain responses', PNAS,.

Chellappa, S. L., Gordijn, M. C. M. and Cajochen, C. (2011) 'Can light make us bright? Effects of light on cognition and sleep', in Progress in Brain Research. doi: 10.1016/B978-0-444-538178.00007-4.

IWATA, T. et al. (1992) 'EXPERIMENTAL STUDY ON DISCOMFORT GLARE CAUSED BY WINDOWS : Subjective response to glare from a simulated window', Journal of Architecture, Planning and Environmental Engineering (Transactions of AlJ). doi: 10.3130/aijax.432.0_21.

Jin, H. et al. (2017) 'An evaluation of the lighting environment in the public space of shopping centres', Building and Environment, 115, pp. 228-235. doi: 10.1016/j.buildenv.2017.01.008.

Kawasaki, A. et al. (2018) 'Impact of long-term daylight deprivation on retinal light sensitivity, circadian rhythms and sleep during the Antarctic winter', Scientific Reports, 8(1), pp. 1-12. doi: 10.1038/s41598-018-33450-7.

Kent, M. G. et al. (2016) 'Temporal variables and personal factors in glare sensation', Lighting Research and Technology, 48(6), pp. 689-710. doi: 10.1177/1477153515578310.

Kim, D. H. and Mansfield, K. P. (2016) 'A cross-cultural study on perceived lighting quality and occupants' well-being between UK and South Korea', Energy and Buildings, 119, pp. 211-217. doi: 10.1016/j.enbuild.2016.03.033.

Lee, J. S. and Kim, B. S. (2007) 'Development of the nomo-graph for evaluation on discomfort glare of windows', Solar Energy, 81(6), pp. 799-808. doi: 10.1016/j.solener.2006.09.006.

Moher, D. et al. (2010) 'Preferred reporting items for systematic reviews and meta-analyses: The PRISMA statement', International Journal of Surgery, 8(5), pp. 336-341. doi: 10.1016/j.ijsu.2010.02.007.

Office for National Statistics (2018) Ethnic group, national identity and religion - Office for National Statistics. Available at: https://www.ons.gov.uk/methodology/classificationsandstandards/measuringequality/ethnicgro upnationalidentityandreligion (Accessed: 1 January 2020).

Park, N. K., Pae, J. Y. and Meneely, J. (2010) 'Cultural preferences in hotel guestroom lighting design', Journal of Interior Design, 36(1), pp. 21-34. doi: 10.1111/j.1939-1668.2010.01046.x.

Pierson, C., Wienold, J. and Bodart, M. (2018) 'Review of Factors Influencing Discomfort Glare Perception from Daylight', LEUKOS - Journal of Illuminating Engineering Society of North America. Taylor \& Francis, 14(3), pp. 111-148. doi: 10.1080/15502724.2018.1428617.

Quellman, E. M. and Boyce, P. R. (2002) 'The light source color preferences of people of different skin tones', Journal of the Illuminating Engineering Society, 31(1), pp. 109-118. doi: 10.1080/00994480.2002.10748376.

Saraiva, T. S. et al. (2018) 'Environmental comfort indicators for school buildings in sustainability assessment tools', Sustainability (Switzerland), 10(6), pp. 1-11. doi: $10.3390 /$ su10061849.

Siu-Yu Lau, S., Gou, Z. and Li, F. M. (2010) 'Users' perceptions of domestic windows in Hong Kong: Challenging daylighting-based design regulations', Journal of Building Appraisal, 6(1), pp. 81-93. doi: 10.1057/jba.2010.12.

Smith, K. A., Schoen, M. W. and Czeisler, C. A. (2004) 'Adaptation of human pineal melatonin suppression by recent photic history', Journal of Clinical Endocrinology and Metabolism, 89(7), pp. 3610-3614. doi: 10.1210/jc.2003-032100.

Spitschan, M. (2019) 'Differences in rod sensitivity due to photic history?', Pain, 160(10), p. 2409. doi: 10.1097/j.pain.0000000000001653.

Subova, A. et al. (1991) 'RESULTS OF AN ONGOING EXPERIMENTS ON SUBJECTIVE 
RESPONSE DISCOMFORT GLARE', Journal of the Illuminating Engineering Institute of JapanJOURNAL OF THE ILLUMINATING ENGINEERING INSTITUTE OF JAPAN. doi: 10.2150/jieij1980.75.appendix_129.

TOKURA, M., IWATA, T. and SHUKUYA, M. (1996) 'EXPERIMENTAL STUDY ON DISCOMFORT GLARE CAUSED BY WINDOWS PART 3: Development of a method for evaluating discomfort glare from a large light source', Journal of Architecture and Planning (Transactions of AlJ), 61(489), pp. 17-25. doi: 10.3130/aija.61.17_8.

Wienold, J. and Christoffersen, J. (2006) 'Evaluation methods and development of a new glare prediction model for daylight environments with the use of CCD cameras', Energy and Buildings, 38(7), pp. 743-757. doi: 10.1016/j.enbuild.2006.03.017. 
Appendix 1 - The studies included in the the qualitative synthesis $(\mathrm{N}=8)$

\begin{tabular}{|c|c|c|c|c|c|c|c|c|c|c|c|}
\hline & $\begin{array}{l}\text { Reviewed } \\
\text { Articles }\end{array}$ & Concept & $\begin{array}{l}\text { Participant } \\
\text { interventions }\end{array}$ & $\begin{array}{l}\text { Experiment } \\
\text { parameters }\end{array}$ & $\begin{array}{l}\text { Physiologi } \\
\text { cal Metrics }\end{array}$ & $\begin{array}{l}\text { Evaluation of } \\
\text { vocabulary }\end{array}$ & Objective (s) & Methodology & $\begin{array}{l}\text { No of } \\
\text { Participants }\end{array}$ & Key Findings & Keynotes \\
\hline 1 & $\begin{array}{l}\text { Lee and Kim, } \\
2007\end{array}$ & $\begin{array}{l}\text { Ethnicity } \\
\text { and } \\
\text { genetic } \\
\text { origin }\end{array}$ & $\begin{array}{l}\text { a) Distance (R) } \\
\text { between the window } \\
\text { and subject } \\
\text { b) Horizontal } \\
\text { distance between the } \\
\text { centre of a window } \\
\text { and subject's eyes (T) } \\
\text { c) Vertical distance } \\
\text { between the centre } \\
\text { of a window and a } \\
\text { subject's eyes (H) } \\
\text { d) Angle of the } \\
\text { window and a } \\
\text { subject's direction of } \\
\text { vision (Q) } \\
\text { e) Position index (P) }\end{array}$ & $\begin{array}{l}\text { a) Window } \\
\text { luminance } \\
\text { (Ls) (cd/m2): } \\
23000,15000 \text {, } \\
8000,5000,30 \\
00 \\
\text { b) } \\
\text { Background } \\
\text { luminance } \\
\text { (Lb) }(\mathrm{cd} / \mathrm{m} 2): \\
318,159,63 \\
\text { c) Work place } \\
\text { illuminance } \\
\text { (lx): } \\
\text { 1000,500,200 }\end{array}$ & $\begin{array}{l}\text { a) Visual } \\
\text { ability tests } \\
\text { to select } \\
\text { participant } \\
\text { s with } \\
\text { corrected } \\
\text { vision } \\
\text { above 1.0) }\end{array}$ & $\begin{array}{l}\text { a) Glare sensation vote } \\
\text { (GSV) (Intolerable - } \\
\text { perceptible) } \\
\text { b) Discomfort sensation } \\
\text { vote (DSV) (very } \\
\text { uncomfortable - not } \\
\text { uncomfortable) } \\
\text { c) Satisfied vote (SV) } \\
\text { (very unsatisfied - } \\
\text { satisfied) } \\
\text { d) Brightness } \\
\text { (Intolerably glaring - } \\
\text { not glaring) } \\
\text { e) Workability } \\
\text { (extremely difficult - no } \\
\text { change) }\end{array}$ & $\begin{array}{l}\text { a) Evaluation of } \\
\text { the visual } \\
\text { difference } \\
\text { between } \\
\text { Caucasians and } \\
\text { Asians because of } \\
\text { the physiological } \\
\text { properties of eyes }\end{array}$ & $\begin{array}{l}\text { a) Mock-up } \\
\text { b) Analysis of the } \\
\text { difference } \\
\text { between the } \\
\text { previous and } \\
\text { present studies' } \\
\text { equations } \\
\text { c) Establishment } \\
\text { of a nomograph }\end{array}$ & $\begin{array}{l}42 \text { Caucasians } \\
\text { and Asians } \\
\text { aged between } \\
20 \text { and } 50 \\
\text { ( } 27 \text { female and } \\
15 \text { male with } \\
\text { corrected } \\
\text { vision above } \\
1.0)\end{array}$ & $\begin{array}{l}\text { a) Caucasians felt } \\
\text { more discomfort } \\
\text { glare at high } \\
\text { luminance of } \\
15,000 \\
\text { b) The recovery } \\
\text { time for a } \\
\text { subject's eyes } \\
\text { after exposure to } \\
\text { a window with } \\
\text { high luminance } \\
\text { was different } \\
\text { depending on the } \\
\text { location of the } \\
\text { subject's eyes and } \\
\text { window }\end{array}$ & $\begin{array}{l}\text { They just focus } \\
\text { on ethnicity } \\
\text { regardless of } \\
\text { their residence } \\
\text { area or prior } \\
\text { light history } \\
\text { They use the } \\
\text { word "culture" } \\
\text { as the long-term } \\
\text { light history } \\
\text { because of their } \\
\text { residence. }\end{array}$ \\
\hline 2 & $\begin{array}{l}\text { Kim and } \\
\text { Mansfield, } \\
2016\end{array}$ & $\begin{array}{l}\text { Area of } \\
\text { residenc } \\
\mathrm{e}\end{array}$ & --- & --- & --- & $\begin{array}{l}\text { a) Lighting quality } \\
\text { Reflection, Flicker, } \\
\text { Brightness, Colour } \\
\text { rendering, Distribution, } \\
\text { Shadows, Overall } \\
\text { Comfort } \\
\text { b) Mood } \\
\text { Aroused - sleepy, } \\
\text { Unpleasant- pleasant } \\
\text { from Affect Grid } \\
\text { (Russell, Weiss and } \\
\text { Mendelsohn, 1989) } \\
\text { c) Lighting appearance } \\
\text { Attractiveness } \\
\text { d) Environmental } \\
\text { satisfaction } \\
\text { Efficiency, Overall } \\
\text { Satisfaction Suitability, } \\
\text { Suitability to the tasks, } \\
\text { Preference } \\
\text { e) Eye discomfort } \\
\text { Negative sensitivity, } \\
\text { Redness, Tiredness, } \\
\text { Dryness } \\
\text { (1-5 (higher is better)) }\end{array}$ & $\begin{array}{l}\text { a) Investigation of } \\
\text { the appraisal path } \\
\text { in the cultural } \\
\text { differences } \\
\text { between the UK } \\
\text { and South Korea } \\
\text { with daylit and } \\
\text { non-daylit cafes }\end{array}$ & $\begin{array}{l}\text { a) Two field } \\
\text { surveys } \\
\text { conducted in } \\
\text { London, UK and } \\
\text { Seoul, South } \\
\text { Korea. One daylit, } \\
\text { and non-daylit } \\
\text { café were } \\
\text { surveyed in each } \\
\text { country, with the } \\
\text { participants spent } \\
\text { at least } 30 \\
\text { minutes in the } \\
\text { café. }\end{array}$ & $\begin{array}{l}66 \text { customers } \\
\text { (49 for daylit, } \\
17 \text { for non- } \\
\text { daylit) in } \\
\text { London } \\
102 \text { customers } \\
\text { (62 for daylit, } \\
40 \text { for non- } \\
\text { daylit) in Seoul }\end{array}$ & $\begin{array}{l}\text { a) There is a } \\
\text { cultural difference } \\
\text { in the appraisal } \\
\text { path between the } \\
\text { UK and South } \\
\text { Korea, and this } \\
\text { would be worth } \\
\text { exploring further } \\
\text { with different } \\
\text { cultural cohorts. } \\
\text { b) Appraisal path } \\
\text { can be a useful } \\
\text { model for } \\
\text { determining the } \\
\text { effect of luminous } \\
\text { conditions on } \\
\text { occupant } \\
\text { appraisal, } \\
\text { preference, mood } \\
\text { and health and } \\
\text { well-being. }\end{array}$ & $\begin{array}{l}\text { They assume } \\
\text { that the people } \\
\text { living in the } \\
\text { same place have } \\
\text { a common } \\
\text { culture, but } \\
\text { maybe different } \\
\text { factors are } \\
\text { affecting their } \\
\text { light } \\
\text { judgements. }\end{array}$ \\
\hline
\end{tabular}




\begin{tabular}{|c|c|c|c|c|c|c|c|c|c|c|c|}
\hline 3 & $\begin{array}{l}\text { Saraiva et } \\
\text { al., } 2018\end{array}$ & $\begin{array}{l}\text { Area of } \\
\text { residenc } \\
\text { e }\end{array}$ & --- & $\begin{array}{l}\text { a) Dimensions } \\
\text { of the classes } \\
\text { b) Air quality, } \\
\text { c) Thermal } \\
\text { comfort, } \\
\text { d) Visual } \\
\text { comfort and } \\
\text { e) Acoustic } \\
\text { comfort } \\
\text { components } \\
\text { were } \\
\text { described and } \\
\text { compared. }\end{array}$ & --- & $\begin{array}{l}\text { a) Indoor air quality } \\
\text { (Fresh-very polluted) } \\
\text { b) Thermal comfort } \\
\text { (Comfortable - Very } \\
\text { uncomfortable with } \\
\text { very warm) } \\
\text { c) Visual comfort } \\
\text { (Comfortable - Very } \\
\text { uncomfortable with } \\
\text { very insufficient } \\
\text { lighting) } \\
\text { d) Acoustic comfort } \\
\text { (Comfortable- very } \\
\text { noisy) } \\
\text { e) Ergonomic comfort } \\
\text { (comfortable-very } \\
\text { uncomfortable) }\end{array}$ & $\begin{array}{l}\text { a) This research } \\
\text { addresses the } \\
\text { importance of } \\
\text { using indicators } \\
\text { related to } \\
\text { environmental } \\
\text { comfort in } \\
\text { sustainability } \\
\text { assessment tools } \\
\text { applied to school } \\
\text { buildings. }\end{array}$ & $\begin{array}{l}\text { a) conducted in } \\
\text { two different } \\
\text { cities, Guimarães } \\
\text { in Portugal and } \\
\text { Juiz de Fora in } \\
\text { Brazil with similar } \\
\text { climate conditions } \\
\text { (temperature and } \\
\text { air humidity). } \\
\text { b) adapted } \\
\text { version of Ricardo } \\
\text { Mateus' thesis } \\
\text { was used } \\
\text { to assess the } \\
\text { Indoor } \\
\text { Environmental } \\
\text { Quality (IEQ) } \\
\text { conditions in the } \\
\text { school buildings. }\end{array}$ & $\begin{array}{l}269 \text { students in } \\
\text { Portugal and } \\
269 \text { students in } \\
\text { Brazil aged } \\
\text { between } \\
15 \text { and } 18 .\end{array}$ & $\begin{array}{l}\text { a) There is no } \\
\text { noticeable } \\
\text { variation between } \\
\text { the countries. } \\
\text { Both Brazilian and } \\
\text { Portuguese } \\
\text { students have } \\
\text { very similar } \\
\text { parameters in } \\
\text { school buildings. } \\
\text { b) There is } \\
\text { considerable } \\
\text { variability } \\
\text { in IEQ between th } \\
\text { e countries. } \\
\text { c) Light } \\
\text { satisfaction of } \\
\text { them are quite } \\
\text { similar (78\% in } \\
\text { Portugal and } 80 \% \\
\text { in Brazil) }\end{array}$ & $\begin{array}{l}\text { Although these } \\
\text { students live in } \\
\text { different } \\
\text { countries, and } \\
\text { they have } \\
\text { different cultural } \\
\text { backgrounds, } \\
\text { their light } \\
\text { satisfaction is } \\
\text { similar, probably } \\
\text { due to similar } \\
\text { climate } \\
\text { conditions they } \\
\text { exposed to. }\end{array}$ \\
\hline 4 & $\begin{array}{l}\text { Brandl and } \\
\text { Lachenmayr, } \\
1994\end{array}$ & $\begin{array}{l}\text { Area of } \\
\text { residenc } \\
\text { e }\end{array}$ & --- & $\begin{array}{l}\text { a) } \\
\text { Participants } \\
\text { were } \\
\text { examined in } \\
\text { the altitude } \\
\text { simulation } \\
\text { chamber of } \\
\text { the Aviation } \\
\text { Medicine } \\
\text { Institute of } \\
\text { German Air } \\
\text { Force at zero } \\
\text { altitudes (= } \\
500 \mathrm{~m}) \text { and } \\
10,000 \mathrm{ft} \text { (ca. } \\
3,500 \mathrm{~m} \\
\text { height). }\end{array}$ & $\begin{array}{l}\text { Heidelberg } \\
\text { anomalosc } \\
\text { ope }\end{array}$ & $\begin{array}{l}\text { a) D-15 test } \\
\text { b) Humphrey Field } \\
\text { Analyzer }\end{array}$ & $\begin{array}{l}\text { a) Testing the } \\
\text { dependency of } \\
\text { changes in the } \\
\text { central visual field } \\
\text { sensitivity on } \\
\text { different degrees } \\
\text { of oxygen } \\
\text { saturation }\end{array}$ & $\begin{array}{l}\text { a) Determination } \\
\text { of abnormal } \\
\text { quotient using a } \\
\text { Heidelberg } \\
\text { anomaloscope } \\
\text { b) Determination } \\
\text { of changes in } \\
\text { colour vision by } \\
\text { saturated and } \\
\text { desaturated panel } \\
\text { D-15 test } \\
\text { c) Determination } \\
\text { of differences in } \\
\text { light sensitivity } \\
\text { for the white, red, } \\
\text { blue and green } \\
\text { light by a } \\
\text { threshold test } \\
\text { using a Humphrey } \\
\text { Field Analyzer } \\
\text { (640) as a } \\
\text { perimeter. }\end{array}$ & $\begin{array}{l}48 \text { probands } \\
\text { ( } 48 \text { monocular } \\
\text { tests) } 20-50 \\
\text { years of age }\end{array}$ & $\begin{array}{l}\text { a) At zero level } \\
\text { (500 } \mathrm{m}) \\
\text { hemoglobin- } \\
\text { oxygen saturation } \\
\text { was } 97 \%+/-1 \% \text {. } \\
\text { b) At } 10,000 \mathrm{ft} \text { this } \\
\text { value decreased } \\
\text { to } 83 \%+/-3 \% \text {. } \\
\text { Hypoxic hypoxia } \\
\text { caused neither } \\
\text { significant AQ } \\
\text { changes, nor did it } \\
\text { induce } \\
\text { reproducible } \\
\text { changes in colour } \\
\text { vision by the panel } \\
D-15 \text { test. } \\
\text { c) Anoxia resulted } \\
\text { in significant } \\
\text { (P< } 0.01 \text { ) } \\
\text { differences in } \\
\text { light sensitivity in } \\
\text { phototopic range. }\end{array}$ & $\begin{array}{l}\text { It shows that } \\
\text { altitude change } \\
\text { makes some } \\
\text { differences in } \\
\text { our light } \\
\text { sensitivity. }\end{array}$ \\
\hline
\end{tabular}




\begin{tabular}{|c|c|c|c|c|c|c|c|c|c|c|c|}
\hline 5 & $\begin{array}{l}\text { Kent et al., } \\
2016\end{array}$ & $\begin{array}{l}\text { Short } \\
\text { term } \\
\text { light } \\
\text { exposure }\end{array}$ & $\begin{array}{l}\text { a) During the } \\
\text { experiments, } \\
\text { participants were } \\
\text { asked to focus } \\
\text { attention on } \\
\text { a visual fixation point } \\
\text { positioned in the } \\
\text { centre of a screen } \\
\text { whose luminance was } \\
\text { slowly raised at a ste } \\
\text { ady rate. } \\
\text { b) Subjects were } \\
\text { required to } \\
\text { participate in the } \\
\text { experiment on the } \\
\text { same day in four test } \\
\text { sessions at } 3 \text {-hour } \\
\text { intervals: } \\
\text { Morning: } 09: 00 \text { or } \\
09: 30 \\
\text { Evening: } 18: 00 \text { or } \\
\text { 18:30 } \\
\text { Afternoon B: } 15: 00 \text { or } \\
\text { 15:30 } \\
\text { Afternoon A: } 12: 00 \text { or } \\
\text { 12:30 }\end{array}$ & -- & --- & $\begin{array}{l}\text { a) Photosensitivity } \\
\text { Self-assessed exposure } \\
\text { to natural and artificial } \\
\text { light, their usage of } \\
\text { solar protections such } \\
\text { as sunglasses, their } \\
\text { luminous routines such } \\
\text { as working at a bright or } \\
\text { dark condition } \\
\text { consistently, and their } \\
\text { interaction with } \\
\text { environment such as } \\
\text { blinds. } \\
\text { b) Chronotype } \\
\text { Questions from the } \\
\text { Munich Chronotype } \\
\text { Questionnaire (MCTQ) } \\
\text { (Roenneberg, Wirz- } \\
\text { Justice and Merrow, } \\
\text { 2003) } \\
\text { c) Glare sensation votes } \\
\text { (GSV) } \\
\text { d) Temporal variables } \\
\text { question assessing } \\
\text { participants' fatigue } \\
\text { level, caffeine and food } \\
\text { intake before the } \\
\text { experiment, the most } \\
\text { exposed sky conditions } \\
\text { and natural-artificial } \\
\text { light between test } \\
\text { sessions. }\end{array}$ & $\begin{array}{l}\text { a) Investigation of } \\
\text { the impact of } \\
\text { various temporal } \\
\text { variables } \\
\text {, in other words, } \\
\text { the variables } \\
\text { covarying with the } \\
\text { time of the day } \\
\text { and commonly } \\
\text { associated } \\
\text { personal factors } \\
\text { with subjective } \\
\text { evaluations of } \\
\text { glare sensation as } \\
\text { the day progresses. }\end{array}$ & $\begin{array}{l}\text { a) Controlled } \\
\text { laboratory } \\
\text { experiments with } \\
\text { the same } \\
\text { participants at } \\
\text { different times of } \\
\text { the day }\end{array}$ & 30 participants & $\begin{array}{l}\text { a) Earlier } \\
\text { Chronotype test } \\
\text { subjects were able } \\
\text { to tolerate higher } \\
\text { levels of source } \\
\text { luminance for the } \\
\text { same reported } \\
\text { criteria of visual } \\
\text { discomfort at all } \\
\text { times of the day. } \\
\text { b) There is higher } \\
\text { tolerance to } \\
\text { source luminance } \\
\text { across all criteria } \\
\text { of glare sensation } \\
\text { throughout the } \\
\text { day for subjects } \\
\text { not having } \\
\text { ingested caffeine. } \\
\text { c) Age, gender, } \\
\text { ethnicity, food } \\
\text { ingestion and self- } \\
\text { assessed } \\
\text { photosensitivity of } \\
\text { participants did } \\
\text { not show any } \\
\text { statistically } \\
\text { significant } \\
\text { difference } \\
\text { between } \\
\text { subjective } \\
\text { evaluations of } \\
\text { glare sensation. } \\
\text { d) There is no } \\
\text { influence of } \\
\text { fatigue, sky } \\
\text { conditions, and } \\
\text { prior light } \\
\text { exposure on } \\
\text { individual glare } \\
\text { sensations at } \\
\text { different levels of } \\
\text { visual discomfort } \\
\text { and times of the } \\
\text { day. }\end{array}$ & $\begin{array}{l}\text { Although they } \\
\text { have found no } \\
\text { effect of prior } \\
\text { history on glare } \\
\text { sensation in this } \\
\text { study, they } \\
\text { found a } \\
\text { significant } \\
\text { difference in } \\
\text { their further } \\
\text { studies. }\end{array}$ \\
\hline
\end{tabular}




\begin{tabular}{|c|c|c|c|c|c|c|c|c|c|c|c|}
\hline 6 & $\begin{array}{l}\text { Martin et } \\
\text { al., } 2002\end{array}$ & $\begin{array}{l}\text { Short } \\
\text { term } \\
\text { light } \\
\text { exposure }\end{array}$ & $\begin{array}{l}\text { a) limited time spent } \\
\text { outside in the dim } \\
\text { week }\end{array}$ & --- & $\begin{array}{l}\text { a) Baseline } \\
\text { and test } \\
\text { melatonin } \\
\text { suppressio } \\
\mathrm{n}\end{array}$ & $\begin{array}{l}\text { a) Sleep schedule } \\
\text { b) Dim- and bright-week } \\
\text { conditions } \\
\text { (During the dim week, } \\
\text { subjects were } \\
\text { instructed to minimise } \\
\text { their outdoor light } \\
\text { exposure and to wear } \\
\text { dark welders' goggles) }\end{array}$ & $\begin{array}{l}\text { a) Analysing light } \\
\text { exposure history } \\
\text { impact on } \\
\text { subjective light } \\
\text { sensitivity, as } \\
\text { assessed by the } \\
\text { magnitude of the } \\
\text { suppression of } \\
\text { melatonin } \\
\text { secretion by } \\
\text { nocturnal light. } \\
\text { b) The hypothesis } \\
\text { was that following } \\
\text { a week of } \\
\text { increased daytime } \\
\text { bright-light } \\
\text { exposure, subjects } \\
\text { would become less } \\
\text { sensitive to light } \\
\text { and that after a } \\
\text { week of restriction } \\
\text { to the dimmer } \\
\text { light, they would } \\
\text { become more } \\
\text { sensitive. }\end{array}$ & $\begin{array}{l}\text { a) The protocol } \\
\text { was a counter- } \\
\text { balanced } \\
\text { crossover design, } \\
\text { composed of a } \\
\text { dim week and a } \\
\text { bright week, } \\
\text { lasting a total of } \\
14 \text { consecutive } \\
\text { days. Seven } \\
\text { subjects } \\
\text { completed the } \\
\text { bright week first, } \\
\text { and five subjects } \\
\text { completed the } \\
\text { dim week first. }\end{array}$ & $\begin{array}{l}\text { a) A total of } 12 \\
\text { healthy } \\
\text { subjects, six } \\
\text { females and six } \\
\text { males } \\
\text { (mean age } \\
25.5 \text { ) } \\
\text { b) None of the } \\
\text { subjects was } \\
\text { taking } \\
\text { prescription } \\
\text { medications } \\
\text { working night } \\
\text { shifts or had } \\
\text { travelled } \\
\text { through more } \\
\text { than two time } \\
\text { zones one } \\
\text { month } \\
\text { preceding the } \\
\text { experiment. }\end{array}$ & $\begin{array}{l}\text { a) This study was } \\
\text { the first to show } \\
\text { that light } \\
\text { sensitivity in } \\
\text { humans, as } \\
\text { assessed by } \\
\text { melatonin } \\
\text { suppression to } \\
\text { nocturnal light, } \\
\text { may be changed } \\
\text { by manipulating } \\
\text { light exposure } \\
\text { history in the } \\
\text { previous week. } \\
\text { b) Significantly } \\
\text { more melatonin } \\
\text { suppression after } \\
\text { a week of } \\
\text { exposure to } \\
\text { relatively dim } \\
\text { light compared } \\
\text { with after a week } \\
\text { of exposure to } \\
\text { long durations } \\
\text { (about } 4 \text { hr per } \\
\text { day) of brighter } \\
\text { light, suggesting } \\
\text { higher light } \\
\text { sensitivity after } \\
\text { the dim week } \\
\text { when compared } \\
\text { with the bright } \\
\text { week. }\end{array}$ & $\begin{array}{l}\text { Although they } \\
\text { found that prior } \\
\text { light history has } \\
\text { an impact on } \\
\text { melatonin } \\
\text { amount and } \\
\text { circadian } \\
\text { rhythm, the light } \\
\text { exposure time is } \\
\text { too short, and it } \\
\text { was suggested } \\
\text { that it should be } \\
\text { tested with more } \\
\text { extended } \\
\text { studies. }\end{array}$ \\
\hline 7 & $\begin{array}{l}\text { Kawasaki et } \\
\text { al., } 2018\end{array}$ & $\begin{array}{l}\text { Short } \\
\text { term } \\
\text { light } \\
\text { exposure }\end{array}$ & --- & --- & $\begin{array}{l}\text { a)Pupillogr } \\
\text { aphy } \\
\text { b) } \\
\text { Circadian } \\
\text { rhythm } \\
\text { analysis } \\
\text { c) Sleep } \\
\text { (derived } \\
\text { from rest- } \\
\text { activity } \\
\text { recordings) }\end{array}$ & --- & $\begin{array}{l}\text { a) Testing whether } \\
\text { retinal sensitivity, } \\
\text { sleep, and } \\
\text { circadian rest- } \\
\text { activity will change } \\
\text { during long-term } \\
\text { daylight } \\
\text { deprivation on two } \\
\text { Antarctic bases } \\
\text { (Concordia and } \\
\text { Halley VI) }\end{array}$ & $\begin{array}{l}\text { a) Evaluation of } \\
\text { retinal sensitivity } \\
\text { changes analysing } \\
\text { the pupil } \\
\text { responses } \\
\text { towards different } \\
\text { light stimuli. } \\
\text { b) Sedentary and } \\
\text { active periods } \\
\text { continuously } \\
\text { measured using } \\
\text { activity watches }\end{array}$ & $\begin{array}{l}25 \text { healthy } \\
\text { people (mean } \\
\text { age: } 34 \pm 11 y \text {; } \\
7 f \text { ) }\end{array}$ & $\begin{array}{l}\text { a) During long- } \\
\text { term daylight } \\
\text { deprivation, } \\
\text { retinal sensitivity } \\
\text { to blue light } \\
\text { increases, } \\
\text { whereas circadian } \\
\text { rhythm stability } \\
\text { decreases, and } \\
\text { sleep-wake timing } \\
\text { is delayed. } \\
\text { b) The sleep-wake } \\
\text { cycle obtained }\end{array}$ & $\begin{array}{l}\text { It shows that } \\
\text { daylight } \\
\text { deprivation for } \\
\text { seven months } \\
\text { make some } \\
\text { changes in our } \\
\text { retinal sensitivity } \\
\text { and sleep-wake } \\
\text { pattern. }\end{array}$ \\
\hline
\end{tabular}


Izmir Tunahan, G.et al. CONCEPTUAL FRAMEWORK OF CULTURAL BACKGROUND IN THE LIT ENVIRONMENT

\begin{tabular}{|c|c|c|c|c|c|c|c|c|c|c|c|}
\hline & & & & & & & & & & $\begin{array}{l}\text { from the } \\
\text { information rest- } \\
\text { activity } \\
\\
\text { recordings was } \\
\text { significantly } \\
\text { delayed after the } \\
\text { first-month } \\
\text { daylight } \\
\text { deprivation ( } p< \\
0.05) \text {. }\end{array}$ & \\
\hline 8 & $\begin{array}{l}\text { Siu-Yu Lau, } \\
\text { Gou and Li, } \\
2010\end{array}$ & $\begin{array}{l}\text { Sociocult } \\
\text { ural } \\
\text { effect }\end{array}$ & --- & --- & --- & $\begin{array}{l}\text { (a) Background } \\
\text { information, } \\
\text { (b) Lifestyle and living } \\
\text { habits, } \\
\text { (c) Design of windows } \\
\text { (d) Window evaluation }\end{array}$ & $\begin{array}{l}\text { a) Investigation of } \\
\text { Human - window } \\
\text { interaction in the } \\
\text { residential } \\
\text { buildings in Hong } \\
\text { Kong } \\
\text { b) Increase of the } \\
\text { satisfaction of the } \\
\text { building users in } \\
\text { daylight }\end{array}$ & $\begin{array}{l}\text { A questionnaire } \\
\text { was conducted } \\
\text { between } \\
\text { December } 2007 \\
\text { and June } 2008 \text { to } \\
\text { investigate } \\
\text { window and } \\
\text { human } \\
\text { interactions in } \\
\text { high-rise } \\
\text { residential } \\
\text { buildings in Hong } \\
\text { Kong. }\end{array}$ & $\begin{array}{l}300 \\
\text { questionnaires } \\
\text { were circulated } \\
\text { in both private } \\
\text { and public } \\
\text { housings in } \\
\text { Hong Kong but } \\
\text { only } 200 \text { ones } \\
\text { were filled out } \\
\text { which only } 173 \\
\text { were valid for } \\
\text { further } \\
\text { analysis. }\end{array}$ & $\begin{array}{l}\text { a) The study } \\
\text { results showed } \\
\text { that daylighting is } \\
\text { not the dominant } \\
\text { factor for } \\
\text { domestic window } \\
\text { design because of } \\
\text { Hong Kong's } \\
\text { sociocultural } \\
\text { context. However, } \\
\text { other factors such } \\
\text { as dining habits, } \\
\text { views from the } \\
\text { living room, and } \\
\text { privacy for the } \\
\text { bedroom proved } \\
\text { to be more } \\
\text { important in the } \\
\text { users ' perception. }\end{array}$ & $\begin{array}{l}\text { In some cultures, } \\
\text { daylight may not } \\
\text { be a dominant } \\
\text { factor because } \\
\text { of the socio- } \\
\text { cultural context, } \\
\text { so their } \\
\text { expectation and } \\
\text { satisfaction will } \\
\text { vary from } \\
\text { others. }\end{array}$ \\
\hline
\end{tabular}


Izmir Tunahan, G.et al. CONCEPTUAL FRAMEWORK OF CULTURAL BACKGROUND IN THE LIT ENVIRONMENT 